\title{
Uveal Prolapse
}

National Cancer Institute

\section{Source}

National Cancer Institute. Uveal Prolapse. NCI Thesaurus. Code C118754.

The protrusion of uveal tissue through an opening in the sclera. 